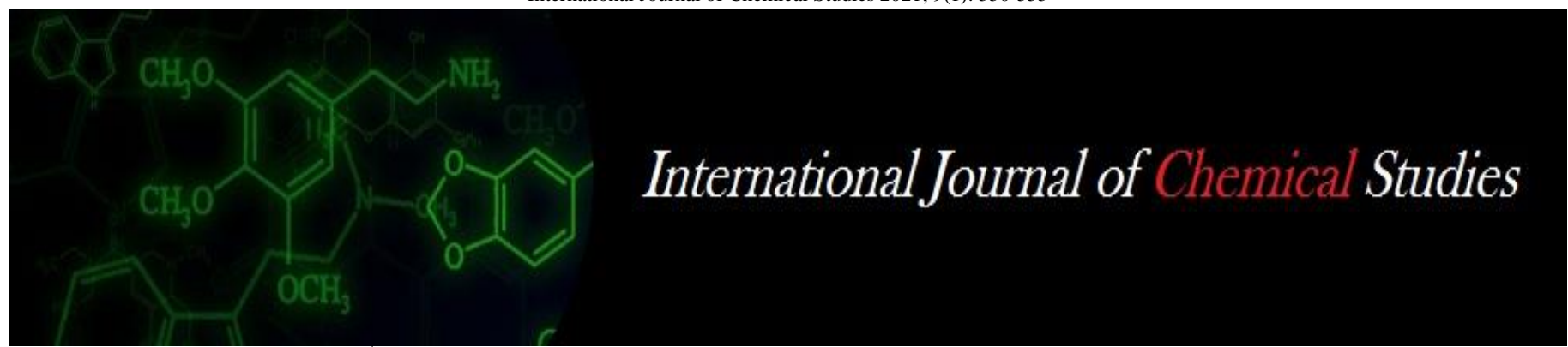

P-ISSN: 2349-8528

E-ISSN: 2321-4902

www.chemijournal.com

IJCS 2021; 9(1): 550-555

(C) 2021 IJCS

Received: 09-10-2020

Accepted: 21-11-2020

\section{Dinesh Thakur}

Department of Basic Sciences,

Dr. YSP UHF Nauni Solan,

Himachal Pradesh, India

\section{Anju Thakur}

Department of Basic Sciences,

Dr. YSP UHF Nauni Solan,

Himachal Pradesh, India

\section{Kartikey Sahil}

Department of Environmental Science, Dr. YSP UHF Nauni

Solan, Himachal Pradesh, India

Corresponding Author:

Kartikey Sahil

Department of Environmental

Science, Dr. YSP UHF Nauni

Solan, Himachal Pradesh, India

\section{Effect of seed priming on seed vigour in Podophyllum hexandrum Royle: An important medicinal herb of temperate Himalayan region}

\author{
Dinesh Thakur, Anju Thakur and Kartikey Sahil
}

DOI: https://doi.org/10.22271/chemi.2021.v9.i1h.11286

\begin{abstract}
The present investigation was conducted with an objective to study the effect of seed priming on seed vigour in Podophyllum hexandrum Royle. The seeds of Podophyllum hexandrum were subjected to seventeen priming treatments and stored thereafter, for 0 , 1and 2 months. Radicle length was found maximum $(4.02 \mathrm{~cm})$ in $\mathrm{T}_{8}$ i.e. $\mathrm{GA}_{3} 100 \mathrm{ppm}$ for 48 hours as compared to the control. Plumule length was maximum i.e. $4.11 \mathrm{~cm}$ which was found in $\mathrm{T}_{8}$ i.e. $\mathrm{GA}_{3} 100 \mathrm{ppm}$ for 48 hours as compared to the control. Untreated (control) seeds showed $19.88 \mathrm{mg}$ seedling dry weight. Whereas it was maximum i.e. $32.58 \mathrm{mg}$ found in $\mathrm{T}_{8}$ i.e. $\mathrm{GA}_{3} 100 \mathrm{ppm}$ for 48 hours as compared to the control, which was followed by $\mathrm{T}_{9}$ i.e. $\mathrm{GA}_{3}$ $100 \mathrm{ppm}$ for 72 hours. Untreated (control) seeds showed seedling vigour index I (SV-I) as 169.0, whereas it was maximum (340.79) found in $\mathrm{T}_{3}$ i.e. hydropriming for 48 hours as compared to the control and closely followed by $\mathrm{T}_{16}$ i.e. brassinolide $1.0 \mathrm{ppm} 48$ hours. Untreated (control) seeds registered 6.68 seedling vigour index II (SV-II). Maximum seedling vigour index II (13.97) was found in $\mathrm{T}_{16}$ i.e. brassinolide $1.0 \mathrm{ppm}$ for 48 hours as compared to the control and followed by $\mathrm{T}_{3}$ i.e. hydropriming for 48 hours. Henceforth, it is concluded that above seed treatments can pave the way for improving vigour of $P$. hexandrum which otherwise shows late, low, and asynchronized germination.
\end{abstract}

Keywords: Seed priming, physiology, Podophyllum hexandrum Royle, seed vigour

\section{Introduction}

Podophyllum hexandrum Royle, endemic to the Himalayas is an endangered medicinal plant (Chaurasia et al., 2012) ${ }^{[4]}$ and also enlisted as an endangered plant in IUCN Red list. National Medicinal Plant Board, India has initiated efforts towards the conservation of rare, endangered, and threatened medicinal plants throughout the country (Ali and Sharma, 2013) ${ }^{[1]}$. It belongs to family Berberidaceae and is a native to the lower elevations of Himalayan countries like Afghanistan, Pakistan, India, Nepal, Bhutan, and Southwest China. In India, Podophyllum hexandrum is mostly found in alpine Himalayas (3000-4500 m) of Jammu and Kashmir, Himachal Pradesh, Sikkim, Uttaranchal, and Arunachal Pradesh. Despite its wider distribution in the entire Indian Himalayan range from Ladakh to Sikkim at an elevation of 3000-4200 m, the current status of $P$. hexandrum is 'endangered' (Nag et al., 2015) ${ }^{[10]}$. It grows in wet alpine meadows, in humus-rich and shaded localities or near stream banks as an undergrowth along with other herbs.

Wild plant raw material is in great demand around the world for use by pharmaceutical companies and ethnomedicinal practitioners in a variety of traditional medicines. India is one of the world's major exporters of raw herbal drugs. The domestic and international demand is met mainly through unsustainable in-situ harvesting which has become a major threat to the survival of many Himalayan plant species (Badola, 2003) ${ }^{[2]}$. There is about 100 ton annual demand of Himalayan Mayapple from international sources, with only 50-80 tonnes of this being met (Ghimire et al., 2006) ${ }^{[6]}$. The estimated yield could range from 330 to $490 \mathrm{~kg} / \mathrm{acre}$ and over $70 \mathrm{~kg}$ of podophyllotoxin extract could be produced per acre cultivated land. Etoposide, a derivative of podophyllotoxin, is currently in clinical use in the treatment of many cancers (Hameed, 2014) ${ }^{[7]}$.

Due to its high medicinal importance and demand, $P$. hexandrum is overexploited rendering its survival at natural sites 'endangered'. The cultivation of this species may answer the growing needs of the plant material. In nature, $P$. hexandrum propagates vegetatively by rhizome and 
sexually by seeds. Therefore, a conservation strategy should be devised to increase its population number by propagating the plant through seeds in a short period, thereby compensating or reducing the harvesting pressure on the medicinally valuable rhizome. The plant raised from rhizome cutting takes 12 years to produces far-sized marketable rhizome, whereas the plants raised from seedling take an even longer time. Since it is subjected to harsh and extended winter conditions and perennates through underground parts for most of the year, the period of growth is confined only to summer months.

Seeds of $P$. hexandrum remain dormant for about 10 months under natural conditions. Since the difficulties of germination have not favored its domestication, this can certainly be explained by a difficult propagation due to late fruiting (after 3-4 years vegetation), very capricious germination, and very slow growth (Bhadwar and Sharma, 1963) [3]. Thus, major problems for the cultivation of this plant are its long juvenile phase and poor fruit setting ability (Qazi et al., 2011) ${ }^{[7]}$. Seeds of $P$. hexandrum show slow, low and asynchronous germination and poor seedling performance. The structure and arrangement of embryonic envelopes act as a barrier in seed germination has been elucidated. The uptake of water by $P$. hexandrum seeds during germination shows a triphasic pattern with a reduced rate of water uptake during Phase III, due to the presence of thick-walled endosperm cells which acts as a physical barrier to the protrusion of the radicle. The existence of the multi-layered endosperm and the thick testa appears to protect the embryo during extreme environmental conditions by preventing germination until conditions are more favourable (Sreenivasulu et al., 2009) ${ }^{[13]}$.

There is an urgent need to develop and implement regeneration/conservation strategies for the exploitation of this medicinal plant. Simultaneous development of ex situ propagation of the species concerned would encourage their cultivation, thereby considerably easing the pressure on natural habitats (Sharma et al., 2006) ${ }^{[12]}$. Attempts have been made to conserve this plant through the artificial breaking of

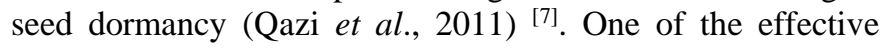
techniques of seed enhancement is priming which can be used to enhance seed quality, rapid and uniform seed emergence, and improve overall germination (McDonald, 2000 and Farooq et al., 2007) ${ }^{[8,5]}$.

Therefore, keeping in view the problems of highly erratic, delayed, poor and asynchronous germination of $P$. hexandrum seeds, the proposed study was undertaken with aim to improve the germination potential and vigour of seeds by using multiple approaches of seed priming.

\section{Methodology}

The present study was conducted in Plant Physiology laboratory of the Department of Basic Sciences, Dr. Y.S. Parmar University of Horticulture and Forestry, Nauni Solan (H.P.) during the period 2014-16. The details of the experiments which were conducted to achieve the objectives and methodologies are given below:

T1: Control

T2: Hydropriming for 24 hours

T3: Hydropriming for 48 hours

T4: Polyethylene glycol (PEG 6000), -0.5 MPa for 48 hours

T5: Polyethylene glycol (PEG 6000), $-0.5 \mathrm{MPa}$ for 72 hours

T6: Polyethylene glycol (PEG 6000), -1.0 MPa for 48 hours

$\mathbf{T}_{7}$ : Polyethylene glycol (PEG 6000), -1.0 MPa for 72 hours

T8: Gibberellic acid $\left(\mathrm{GA}_{3}\right), 100 \mathrm{ppm}$ for 48 hours
T9: Gibberellic acid $\left(\mathrm{GA}_{3}\right)$, 100ppm for 72 hours

T10: Polyethylene glycol (PEG 6000), $-0.5 \mathrm{MPa}+\mathrm{GA}_{3}$ 100ppm for 48 hours

T11: Polyethylene glycol (PEG 6000), $\quad-0.5 \mathrm{MPa}+$ $\mathrm{GA}_{3} 100$ ppm for 72 hours

T12: Potassium nitrate $1 \%$ for 48 hours

T13: Potassium nitrate $1 \%$ for 72 hours

$\mathbf{T}_{14}$ : Brassinolide $0.5 \mathrm{ppm}$ for 48 hours

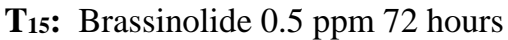

T16: Brassinolide $1.0 \mathrm{ppm}$ for 48 hours

T17: Brassinolide 1.0 ppm for 72 hours

\section{Time of Sowing 3}

1. Direct (0 storage after priming)

2. After storing primed seeds for 1 month

3. After storing primed seeds for 2 months

Number of treatments: 17

Number of treatment combinations: 51

Number of replications: 3 (30 seeds each)

Experimental design: CRD (Factorial)

The experiment was conducted in seed germinator at $20 \pm 2$ ${ }^{\circ} \mathrm{C}, 80 \%$ Relative humidity, and light.

\section{Observations Recorded \\ Source of seeds}

Freshly harvested seeds of Podophyllum hexandrum Royle were procured from Rohru, $(2700-3400 \mathrm{~m}$ amsl) during the last week of September. Thereafter, seeds were cleaned and air-dried. Seed characteristics viz. moisture content, seed viability, and solute leakage were recorded. To study the priming physiology and its implication on seed germination in Podophyllum hexandrum Royle, seeds were surface sterilized with the help of $0.1 \%$ mercuric chloride for 1 minute. Thereafter, seeds were thoroughly washed with distilled water thrice to remove the strains of mercuric chloride completely.

\section{Method of storage}

The primed seeds were packed in sealed in plastic envelopes which in turn were stored in plastic containers at room temperature $\left(25 \pm 2{ }^{\circ} \mathrm{C}\right)$.

\section{Conduct of experiment}

The seeds of Podophyllum hexandrum Royle species were allowed to germinate in Petri dishes using the top paper method in seed germinator at $20 \pm 2{ }^{\circ} \mathrm{C}$ temperature, $80 \%$ relative humidity. The paper used for the experiment was Whatmann no.1.

\section{Observational Procedure \\ Seedling characteristics}

The normal seedlings were selected randomly and seedling characteristics were recorded.

\section{Radicle length (cm)}

Five normal seedlings were selected randomly for measurement of radicle length. The radicle length was measured from the tip of primary root to the base and the mean root length was expressed in centimetres.

\section{Plumule length $(\mathrm{cm})$}

The plumule length was measured from the base of primary leaf to the base of plumule and the mean plumule length was expressed in centimetres. 


\section{Seedling dry weight (mg)}

Five normal seedlings used for measuring the seedling length were kept in the paper bag and dried in a hot air oven at $40 \pm 100 \mathrm{C}$ temperature for 24 hours. Thereafter, seedlings were cooled for 30 minutes and the weight of dried samples were recorded and average dry weight of ten seedlings was expressed in milligrams.

\section{Seedling vigour index- I and II}

Seedling vigour index-I and II were calculated as per the formula given by Abdul Baki and Anderson (1973).

Seedling vigour index-I = Germination percentage $\mathrm{x}$ Seedling length $(\mathrm{cm})$

Seedling vigour index- II = Germination percentage $\mathrm{x}$ Seedling dry weight $(\mathrm{mg})$

\section{Results and Discussion \\ Seedling characteristics \\ Radicle length}

The data pertaining to radicle length of seedlings which were raised from seeds of Podophyllum hexandrum subjected to seventeen priming treatments and stored thereafter for 0,1 and 2 months have been presented in Table 1. Untreated (control) seeds registered $2.70 \mathrm{~cm}$ radicle length. Radicle length was found maximum $(4.02 \mathrm{~cm})$ in $\mathrm{T}_{8}$ i.e. $\mathrm{GA}_{3} 100 \mathrm{ppm}$ for 48 hours as compared to the control. Among treatments, the minimum length of radicle i.e. $1.42 \mathrm{~cm}$ was observed in $\mathrm{T}_{11}$ i.e. PEG $6000(-0.5 \mathrm{MPa})+\mathrm{GA}_{3} 100 \mathrm{ppm}$ for 72 hours. Storage time also exerted a significant effect on radicle length. The maximum length of radicle was $2.40 \mathrm{~cm}$ recorded for 1 month storage and closely followed by 2 months storage i.e. $2.38 \mathrm{~cm}$. However, the minimum length of radicle was $2.30 \mathrm{~cm}$ found for 0 month storage.

Table 1: Effect of priming and storage of seeds on radicle length $(\mathrm{cm})$ in Podophyllum hexandrum

\begin{tabular}{|c|c|c|c|c|}
\hline Storage Duration (D) & 0 month & 1 month & 2 months & Mean \\
\hline $\mathrm{T}_{1}$ : Control & 2.70 & 2.67 & 2.73 & 2.70 \\
\hline $\mathrm{T}_{2}$ : Hydropriming for 24 hours & 2.60 & 2.27 & 2.37 & 2.41 \\
\hline $\mathrm{T}_{3}$ : Hydropriming for 48 hours & 2.93 & 3.00 & 3.13 & 3.02 \\
\hline $\mathrm{T}_{4}$ : Polyethylene glycol (PEG 6000), $-0.5 \mathrm{MPa}$ for 48 hours & 2.43 & 2.10 & 2.37 & 2.30 \\
\hline T5: Polyethylene glycol (PEG 6000), $-0.5 \mathrm{MPa}$ for 72 hours & 1.70 & 2.77 & 1.40 & 1.96 \\
\hline $\mathrm{T}_{6}$ : Polyethylene glycol (PEG 6000), $-1.0 \mathrm{MPa}$ for 48 hours & 1.37 & 1.73 & 1.90 & 1.67 \\
\hline $\mathrm{T}_{7}$ : Polyethylene glycol (PEG 6000), $-1.0 \mathrm{MPa}$ for 72 hours & 1.37 & 1.60 & 1.33 & 1.43 \\
\hline T8: Gibberellic acid $\left(\mathrm{GA}_{3}\right), 100 \mathrm{ppm}$ for 48 hours & 3.73 & 3.93 & 4.40 & 4.02 \\
\hline $\mathrm{T}_{9}$ : Gibberellic acid $\left(\mathrm{GA}_{3}\right), 100 \mathrm{ppm}$ for 72 hours & 3.70 & 3.97 & 4.00 & 3.89 \\
\hline $\mathrm{T}_{10}$ : Polyethylene glycol (PEG 6000), $-0.5 \mathrm{MPa}+\mathrm{GA}_{3} 100 \mathrm{ppm}$ for 48 hours & 1.93 & 1.57 & 1.50 & 1.67 \\
\hline $\mathrm{T}_{11}$ : Polyethylene glycol (PEG 6000), $-0.5 \mathrm{MPa}+\mathrm{GA}_{3} 100 \mathrm{ppm}$ for 72 hours & 1.70 & 1.50 & 1.07 & 1.42 \\
\hline $\mathrm{T}_{12}:$ Potassium nitrate $1 \%$ for 48 hours & 1.30 & 1.47 & 1.53 & 1.43 \\
\hline $\mathrm{T}_{13}$ : Potassium nitrate $1 \%$ for 72 hours & 1.33 & 1.70 & 1.97 & 1.67 \\
\hline $\mathrm{T}_{14}$ : Brassinolide $0.5 \mathrm{ppm}$ for 48 hours & 2.17 & 2.17 & 2.20 & 2.18 \\
\hline $\mathrm{T}_{15}$ : Brassinolide $0.5 \mathrm{ppm} 72$ hours & 2.90 & 2.90 & 2.97 & 2.92 \\
\hline $\mathrm{T}_{16}$ : Brassinolide $1.0 \mathrm{ppm}$ for 48 hours & 2.93 & 3.13 & 3.17 & 3.08 \\
\hline $\mathrm{T}_{17}$ : Brassinolide $1.0 \mathrm{ppm}$ for 72 hours & 2.27 & 2.37 & 2.43 & 2.36 \\
\hline Mean & 2.30 & 2.40 & 2.38 & \\
\hline \multicolumn{5}{|l|}{$\mathrm{CD}_{0.05}$} \\
\hline $\mathrm{T}$ & 0.18 & & & \\
\hline $\mathrm{D}$ & 0.08 & & & \\
\hline $\mathrm{T} \times \mathrm{D}$ & 0.31 & & & \\
\hline
\end{tabular}

\section{Plumule length}

Data pertaining to plumule length of seedlings which were raised from seeds subjected to seventeen priming treatments and stored thereafter for 0,1 and 2 months have been presented in Table 2. Untreated (control) seeds showed plumule length as $2.33 \mathrm{~cm}$. Plumule length was maximum i.e. $4.11 \mathrm{~cm}$ which was found in $\mathrm{T}_{8}$ i.e. $\mathrm{GA}_{3} 100 \mathrm{ppm}$ for 48 hours as compared to the control. Among treatments, the minimum length of plumule was $1.66 \mathrm{~cm}$ which was observed for $\mathrm{T}_{11}$ i.e. PEG $6000(-0.5 \mathrm{MPa})+\mathrm{GA}_{3} 100 \mathrm{ppm}$ for 72 hours. Storage time also exerted a significant effect on plumule length. The maximum length of plumule was $2.43 \mathrm{~cm}$ which was recorded for 2 months storage. However, the minimum length of plumule was $2.29 \mathrm{~cm}$ which was found for 1 month storage.

Table 2: Effect of priming and storage of seeds on plumule length $(\mathrm{cm})$ in Podophyllum hexandrum

\begin{tabular}{|c|c|c|c|c|}
\hline Storage Duration (D) & 0 month & 1 month & 2 months & sMean \\
\hline $\mathrm{T}_{1}$ : Control & 2.30 & 2.30 & 2.40 & 2.33 \\
\hline $\mathrm{T}_{2}$ : Hydropriming for 24 hours & 1.77 & 1.80 & 1.77 & 1.78 \\
\hline$T_{3}$ : Hydropriming for 48 hours & 2.67 & 2.80 & 2.77 & 2.74 \\
\hline $\mathrm{T}_{4}$ : Polyethylene glycol (PEG 6000), $-0.5 \mathrm{MPa}$ for 48 hours & 1.40 & 1.40 & 1.40 & 1.40 \\
\hline $\mathrm{T}_{5}$ : Polyethylene glycol (PEG 6000), $-0.5 \mathrm{MPa}$ for 72 hours & 1.30 & 1.50 & 1.60 & 1.47 \\
\hline T6: Polyethylene glycol (PEG 6000), -1.0 MPa for 48 hours & 2.10 & 1.63 & 2.17 & 1.97 \\
\hline T7: Polyethylene glycol (PEG 6000), $-1.0 \mathrm{MPa}$ for 72 hours & 2.10 & 1.97 & 2.30 & 2.12 \\
\hline $\mathrm{T}_{8}$ : Gibberellic acid $\left(\mathrm{GA}_{3}\right), 100 \mathrm{ppm}$ for 48 hours & 4.10 & 4.03 & 4.20 & 4.11 \\
\hline T9: Gibberellic acid $\left(\mathrm{GA}_{3}\right), 100 \mathrm{ppm}$ for 72 hours & 4.13 & 4.07 & 4.10 & 4.10 \\
\hline $\mathrm{T}_{10}$ : Polyethylene glycol (PEG 6000), $-0.5 \mathrm{MPa}+\mathrm{GA}_{3} 100 \mathrm{ppm}$ for 48 hours & 2.00 & 1.60 & 2.17 & 1.92 \\
\hline $\mathrm{T}_{11}$ : Polyethylene glycol (PEG 6000), $-0.5 \mathrm{MPa}+\mathrm{GA}_{3} 100 \mathrm{ppm}$ for 72 hours & 1.50 & 1.67 & 1.80 & 1.66 \\
\hline
\end{tabular}




\begin{tabular}{|c|c|c|c|c|}
\hline $\mathrm{T}_{12}$ : Potassium nitrate $1 \%$ for 48 hours & 1.80 & 1.73 & 1.93 & 1.82 \\
\hline $\mathrm{T}_{13}$ : Potassium nitrate 1\% for 72 hours & 1.80 & 1.83 & 1.80 & 1.81 \\
\hline $\mathrm{T}_{14}$ : Brassinolide $0.5 \mathrm{ppm}$ for 48 hours & 2.20 & 2.27 & 2.30 & 2.26 \\
\hline $\mathrm{T}_{15}$ : Brassinolide $0.5 \mathrm{ppm} 72$ hours & 2.90 & 2.93 & 3.03 & 2.96 \\
\hline $\mathrm{T}_{16}$ : Brassinolide $1.0 \mathrm{ppm}$ for 48 hours & 2.93 & 2.93 & 3.07 & 2.98 \\
\hline $\mathrm{T}_{17}:$ Brassinolide $1.0 \mathrm{ppm}$ for 72 hours & 2.47 & 2.43 & 2.50 & 2.47 \\
\hline Mean & 2.32 & 2.29 & 2.43 & \\
\hline $\mathrm{CD} 0.05$ & & & & \\
\hline $\mathrm{T}$ & 0.16 & & & \\
\hline $\mathrm{D}$ & 0.07 & & & \\
\hline $\mathrm{T} \times \mathrm{D}$ & $\mathrm{NS}$ & & & \\
\hline
\end{tabular}

\section{Seedling dry weight}

Table 3 reveals the data pertaining to the dry weight of seedlings which were raised from seeds subjected to seventeen priming treatments and stored thereafter for 0,1 and 2 months. Untreated (control) seeds showed $19.88 \mathrm{mg}$ seedling dry weight. Whereas it was maximum i.e. $32.58 \mathrm{mg}$ found in $\mathrm{T}_{8}$ i.e. $\mathrm{GA}_{3} 100 \mathrm{ppm}$ for 48 hours as compared to the control, which was followed by $\mathrm{T}_{9}$ i.e. $\mathrm{GA}_{3} 100 \mathrm{ppm}$ for 72 hours. Among treatments, the minimum seedling dry weight was $14.97 \mathrm{mg}$ in $\mathrm{T}_{5}$ i.e. PEG $6000(-0.5 \mathrm{MPa})$ for 72 hours. Storage time also exerted a significant effect on seedling dry weight. The maximum seedling dry weight was $23.26 \mathrm{mg}$ recorded for 2 months storage and this was followed by 22.97 $\mathrm{mg}$ dry weight as found for 1 month storage. However, the minimum seedling dry weight was $22.53 \mathrm{mg}$ found for 0 month storage.

Table 3: Effect of priming and storage of seeds on seedling dry weight (mg) in Podophyllum hexandrum

\begin{tabular}{|c|c|c|c|c|}
\hline Storage Duration (D) & 0 month & 1 month & 2 months & s Mean \\
\hline $\mathrm{T}_{1}$ : Control & 19.67 & 19.70 & 20.28 & 19.88 \\
\hline $\mathrm{T}_{2}$ : Hydropriming for 24 hours & 19.78 & 19.70 & 19.78 & 19.75 \\
\hline $\mathrm{T}_{3}:$ Hydropriming for 48 hours & 23.37 & 23.56 & 23.63 & 23.52 \\
\hline $\mathrm{T}_{4}$ : Polyethylene glycol (PEG 6000), $-0.5 \mathrm{MPa}$ for 48 hours & 19.44 & 18.67 & 19.41 & 19.17 \\
\hline $\mathrm{T}_{5}$ : Polyethylene glycol (PEG 6000), $-0.5 \mathrm{MPa}$ for 72 hours & 14.82 & 15.15 & 14.93 & 14.97 \\
\hline $\mathrm{T}_{6}$ : Polyethylene glycol (PEG 6000), $-1.0 \mathrm{MPa}$ for 48 hours & 23.56 & 22.63 & 23.31 & 23.17 \\
\hline $\mathrm{T}_{7}$ : Polyethylene glycol (PEG 6000), $-1.0 \mathrm{MPa}$ for 72 hours & 23.75 & 25.30 & 25.82 & 24.95 \\
\hline $\mathrm{T}_{8}:$ Gibberellic acid $\left(\mathrm{GA}_{3}\right), 100 \mathrm{ppm}$ for 48 hours & 31.43 & 31.96 & 34.36 & 32.58 \\
\hline $\mathrm{T}_{9}$ : Gibberellic acid $\left(\mathrm{GA}_{3}\right), 100 \mathrm{ppm}$ for 72 hours & 31.66 & 32.15 & 32.82 & 32.21 \\
\hline $\mathrm{T}_{10}$ : Polyethylene glycol (PEG 6000), $-0.5 \mathrm{MPa}+\mathrm{GA}_{3} 100 \mathrm{ppm}$ for 48 hours & 22.82 & 24.85 & 22.60 & 23.42 \\
\hline $\mathrm{T}_{11}$ : Polyethylene glycol (PEG 6000), $-0.5 \mathrm{MPa}+\mathrm{GA}_{3} 100 \mathrm{ppm}$ for 72 hours & 19.37 & 20.11 & 18.52 & 19.33 \\
\hline $\mathrm{T}_{12}:$ Potassium nitrate $1 \%$ for 48 hours & 19.17 & 19.70 & 21.19 & 20.02 \\
\hline $\mathrm{T}_{13}$ : Potassium nitrate $1 \%$ for 72 hours & 19.52 & 20.88 & 21.61 & 20.67 \\
\hline $\mathrm{T}_{14}$ : Brassinolide $0.5 \mathrm{ppm}$ for 48 hours & 23.18 & 23.18 & 23.91 & 23.43 \\
\hline $\mathrm{T}_{15}$ : Brassinolide $0.5 \mathrm{ppm} 72$ hours & 24.88 & 25.11 & 25.66 & 25.22 \\
\hline $\mathrm{T}_{16}$ : Brassinolide $1.0 \mathrm{ppm}$ for 48 hours & 25.06 & 25.17 & 25.74 & 25.32 \\
\hline $\mathrm{T}_{17}$ : Brassinolide $1.0 \mathrm{ppm}$ for 72 hours & 21.44 & 22.67 & 21.79 & 21.97 \\
\hline Mean & 22.52 & 22.97 & 23.26 & \\
\hline \multicolumn{5}{|l|}{$\mathrm{CD}_{0.05}$} \\
\hline $\mathrm{T}$ & 0.45 & & & \\
\hline $\mathrm{D}$ & 0.19 & & & \\
\hline $\mathrm{T} \times \mathrm{D}$ & 0.78 & & & \\
\hline
\end{tabular}

\section{Seedling vigour index I (SV-I)}

Data pertaining to seedling vigour index I (SV-I) of Podophyllum hexandrum which were subjected to seventeen priming treatments and stored thereafter for 0,1 and 2 months have been presented in Table 4. Untreated (control) seeds showed seedling vigour index I (SV-I) as 169.0, whereas it was maximum (340.79) found in $\mathrm{T}_{3}$ i.e. hydropriming for 48 hours as compared to the control and closely followed by $\mathrm{T}_{16}$ i.e. brassinolide $1.0 \mathrm{ppm} 48$ hours. Among treatments, the minimum seedling vigour index I (SV-I) 40.47 was observed in $\mathrm{T}_{11}$ i.e. PEG $6000(-0.5 \mathrm{MPa})+\mathrm{GA}_{3} 100 \mathrm{ppm}$ for 72 hours. Storage time also exerted a significant effect on seedling vigour index I (SV-I). The maximum seedling vigour index I (202.22) was recorded for 2 months storage which was followed by 1 month storage (177.83). However, the minimum SV-I (155.15) was found for 0 month storage.

Table 4: Effect of seed priming and storage on seedling vigour I (SV-I) in Podophyllum hexandrum

\begin{tabular}{|c|c|c|c|c|}
\hline Priming treatments $(\mathbf{T})$ & Storage Duration $(\mathbf{D})$ & 0 month & $\mathbf{1}$ month 2 months & Mean \\
\hline $\mathrm{T}_{1}$ : Control & 162.40 & 160.39 & 184.24 & 169.01 \\
\hline $\mathrm{T}_{2}$ : Hydropriming for 24 hours & 157.68 & 159.36 & 196.57 & 171.20 \\
\hline $\mathrm{T}_{3}$ : Hydropriming for 48 hours & 273.75 & 345.20 & 403.42 & 340.79 \\
\hline $\mathrm{T}_{4}:$ Polyethylene glycol (PEG 6000), -0.5 MPa for 48 hours & 119.26 & 118.23 & 133.50 & 123.66 \\
\hline $\mathrm{T}_{5}:$ Polyethylene glycol (PEG 6000), -0.5 MPa for 72 hours & 45.77 & 67.80 & 41.56 & 51.71 \\
\hline $\mathrm{T}_{6}:$ Polyethylene glycol (PEG 6000), -1.0 MPa for 48 hours & 87.95 & 93.65 & 122.00 & 101.20 \\
\hline $\mathrm{T}_{7}:$ Polyethylene glycol (PEG 6000), -1.0 MPa for 72 hours & 62.40 & 81.64 & 101.34 & 81.79 \\
\hline $\mathrm{T}_{8}:$ Gibberellic acid (GA 3$), 100 \mathrm{ppm}$ for 48 hours & 273.31 & 315.43 & 347.50 & 312.08 \\
\hline
\end{tabular}




\begin{tabular}{|c|c|c|c|c|}
\hline T9: Gibberellic acid $\left(\mathrm{GA}_{3}\right), 100 \mathrm{ppm}$ for 72 hours & 236.44 & 256.18 & 253.50 & 248.71 \\
\hline $\mathrm{T}_{10}$ : Polyethylene glycol (PEG 6000), $-0.5 \mathrm{MPa}+\mathrm{GA}_{3} 100 \mathrm{ppm}$ for 48 hours & 66.87 & 59.35 & 73.34 & 66.52 \\
\hline $\mathrm{T}_{11}$ : Polyethylene glycol (PEG 6000), $-0.5 \mathrm{MPa}+\mathrm{GA}_{3} 100 \mathrm{ppm}$ for 72 hours & 39.11 & 47.15 & 35.14 & 40.47 \\
\hline $\mathrm{T}_{12}:$ Potassium nitrate $1 \%$ for 48 hours & 130.65 & 135.11 & 149.32 & 138.36 \\
\hline $\mathrm{T}_{13}$ : Potassium nitrate $1 \%$ for 72 hours & 115.01 & 141.33 & 137.56 & 131.30 \\
\hline $\mathrm{T}_{14}$ : Brassinolide $0.5 \mathrm{ppm}$ for 48 hours & 150.24 & 160.42 & 234.99 & 181.88 \\
\hline $\mathrm{T}_{15}$ : Brassinolide $0.5 \mathrm{ppm} 72$ hours & 244.24 & 310.90 & 364.66 & 306.60 \\
\hline $\mathrm{T}_{16}$ : Brassinolide $1.0 \mathrm{ppm}$ for 48 hours & 283.13 & 340.62 & 379.53 & 334.43 \\
\hline $\mathrm{T}_{17}$ : Brassinolide $1.0 \mathrm{ppm}$ for 72 hours & 189.33 & 230.40 & 279.57 & 233.10 \\
\hline Mean & 155.15 & 177.83 & 202.22 & \\
\hline \multicolumn{5}{|l|}{$\mathrm{CD}_{0.05}$} \\
\hline $\mathrm{T}$ & 8.16 & & & \\
\hline $\mathrm{D}$ & 3.43 & & & \\
\hline $\mathrm{T} \times \mathrm{D}$ & 14.13 & & & \\
\hline
\end{tabular}

\section{Seedling vigour index II (SV-II)}

Data pertaining to seedling vigour index II (SV-II) of seeds of Podophyllum hexandrum which were subjected to seventeen priming treatments and stored thereafter for 0,1 and 2 months have been presented in Table 5. Untreated (control) seeds registered 6.68 seedling vigour index II (SV-II). Maximum seedling vigour index II (13.97) was found in $T_{16}$ i.e. brassinolide $1.0 \mathrm{ppm}$ for 48 hours as compared to the control and followed by $\mathrm{T}_{3}$ i.e. hydropriming for 48 hours. Among treatments, the minimum seedling vigour index II (2.24) was observed in $\mathrm{T}_{5}$ i.e. PEG $6000(-0.5 \mathrm{MPa})$ for 72 hours. Storage time also exerted a significant effect on seedling vigour index II (SV-II). The maximum seedling vigour index II 9.41 was recorded for 2 months storage, which was followed by 1 month storage (8.41). However, the minimum seedling vigour index II (SV-II) was 7.33 found for 0 month storage.

Table 5: Effect of seed priming and storage on Seedling vigour index II (SV-II) in Podophyllum hexandrum

\begin{tabular}{|c|c|c|c|c|}
\hline Storage Duration (D) & 0 month & 1 month & 2 months & sMean \\
\hline $\mathrm{T}_{1}$ : Control & 6.39 & 6.36 & 7.28 & 6.68 \\
\hline $\mathrm{T}_{2}$ : Hydropriming for 24 hours & 7.14 & 7.72 & 9.41 & 8.09 \\
\hline $\mathrm{T}_{3}$ : Hydropriming for 48 hours & 11.42 & 14.02 & 16.16 & 13.87 \\
\hline T4: Polyethylene glycol (PEG 6000), $-0.5 \mathrm{MPa}$ for 48 hours & 6.05 & 6.31 & 6.88 & 6.41 \\
\hline $\mathrm{T}_{5}$ : Polyethylene glycol (PEG 6000$),-0.5 \mathrm{MPa}$ for 72 hours & 2.26 & 2.41 & 2.07 & 2.24 \\
\hline $\mathrm{T}_{6}$ : Polyethylene glycol (PEG 6000), $-1.0 \mathrm{MPa}$ for 48 hours & 5.98 & 6.30 & 6.99 & 6.42 \\
\hline T7: Polyethylene glycol (PEG 6000), $-1.0 \mathrm{MPa}$ for 72 hours & 4.27 & 5.79 & 7.20 & 5.75 \\
\hline T8: Gibberellic acid $\left(\mathrm{GA}_{3}\right), 100 \mathrm{ppm}$ for 48 hours & 10.97 & 12.66 & 13.88 & 12.50 \\
\hline $\mathrm{T}_{9}$ : Gibberellic acid $\left(\mathrm{GA}_{3}\right), 100 \mathrm{ppm}$ for 72 hours & 9.56 & 10.25 & 10.27 & 10.03 \\
\hline $\mathrm{T}_{10}$ : Polyethylene glycol (PEG 6000), -0.5 MPa + GA3 100ppm for 48 hours & 3.88 & 4.66 & 4.52 & 4.35 \\
\hline $\mathrm{T}_{11}$ : Polyethylene glycol (PEG 6000), $-0.5 \mathrm{MPa}+\mathrm{GA}_{3} 100 \mathrm{ppm}$ for 72 hours & 2.37 & 2.99 & 2.27 & 2.54 \\
\hline $\mathrm{T}_{12}:$ Potassium nitrate $1 \%$ for 48 hours & 8.08 & 8.32 & 9.13 & 8.51 \\
\hline $\mathrm{T}_{13}$ : Potassium nitrate $1 \%$ for 72 hours & 7.17 & 8.35 & 7.89 & 7.80 \\
\hline $\mathrm{T}_{14}$ : Brassinolide $0.5 \mathrm{ppm}$ for 48 hours & 7.98 & 8.39 & 12.49 & 9.62 \\
\hline $\mathrm{T}_{15}:$ Brassinolide $0.5 \mathrm{ppm} 72$ hours & 10.48 & 13.38 & 15.59 & 13.15 \\
\hline $\mathrm{T}_{16}$ : Brassinolide $1.0 \mathrm{ppm}$ for 48 hours & 12.09 & 14.14 & 15.67 & 13.97 \\
\hline $\mathrm{T}_{17}$ : Brassinolide $1.0 \mathrm{ppm}$ for 72 hours & 8.58 & 10.88 & 12.35 & 10.60 \\
\hline Mean & 7.33 & 8.41 & 9.41 & \\
\hline \multicolumn{5}{|l|}{$\mathrm{CD}_{0.05}$} \\
\hline $\mathrm{T}$ & 0.21 & & & \\
\hline $\mathrm{D}$ & 0.09 & & & \\
\hline $\mathrm{T} \times \mathrm{D}$ & 0.37 & & & \\
\hline
\end{tabular}

\section{Conclusion}

Based on the findings of present investigation it may be concluded that seeds of Podophyllum hexandrum subjected to $\mathrm{GA}_{3} 100 \mathrm{ppm}$ for 48 hours resulted in maximum radicle length $(4.02 \mathrm{~cm})$, plumule length $(4.11 \mathrm{~cm})$ and seedling dry weight $(32.58 \mathrm{mg})$ in $\mathrm{T}_{8}$. The maximum seedling vigour index I (SV-I) of 340.79 was found in $\mathrm{T}_{3}$ i.e. hydropriming for 48 hours as compared to the control and closely followed by $\mathrm{T}_{16}$ i.e. brassinolide $1.0 \mathrm{ppm} 48$ hours whereas the maximum seedling vigour index II (13.97) was found in $\mathrm{T}_{16}$ i.e. brassinolide $1.0 \mathrm{ppm}$ for 48 hours as compared to the control and followed by $\mathrm{T}_{3}$ i.e. hydropriming for 48 hours. Therefore, it was inferred that above seed treatments can pave the way for improving vigour of $P$. hexandrum.

\section{References}

1. Ali M, Sharma V. An Urgent Need for Conservation of Podophyllum hexandrum (Himalyan Mayapple) - An economically important and threatened plant of cold desert of Ladakh, India. The Journal of Biological Chemical Research 2013;30(1):741-747.

2. Badola HK, Aitken S. The Himalayas of India: A treasury of medicinal plants under siege. Biodiversity 2003;4(3):3-13.

3. Bhadwar RL, Sharma BK. A note on germination of Podophyllum seeds. Indian Forester 1963;89:445-447.

4. Chaurasia OP, Ballabh B, Tayade A, Kumar R, Kumar GP, Singh SB. Podophyllum L.: An endangered and anticancerous medicinal plant- An overview. Indian Journal of Traditional Knowledge 2012;11(2):234-241. 
5. Farooq M, Basra SMA, Ahmad N. Improving the performance of transplanted rice by seed priming. Plant Growth Regulation 2007;51:129-137.

6. Ghimire SK, Mckey D, Thomas AY. Himalayan medicinal plant diversity in an ecologically complex high altitude anthropogenic landscape, Dolpo, Nepal. Environmental Conservation 2006;33:1.

7. Hameed I, Ullah A, Murad W, Khan S. Podophyllum hexandrum Royle. Scholarly Journal of Agricultural Science 2014;4(6):331-338.

8. McDonald MB. Seed priming. In: Seed technology and its biological basis. Black $\mathrm{M}$ and Bewley J D. (Eds) Sheffield Academic Press, Sheffield, UK 2000.

9. Moore RP. Tetrazolium staining for assessing seed quality, In Seed Ecology, W. Heydecker ed. University Park Pennsylvania state university press 1973.

10. Nag A, Ahuja PS, Sharma RK. Genetic diversity of highelevation populations of an endangered medicinal plant. AoB Plants 2015;7:1-15.

11. Qazi PH, Rashid A, Shawl SA. Podophyllum hexandrumA versatile medicinal plant. International Journal of Pharmancy and Pharmaceutical Sciences 2011;3:261268.

12. Sharma RK, Sharma S, Sharma SS. Seed germination behaviour of some medicinal plants of Lahaul and Spiti cold desert (Himachal Pradesh): implications for conservation and cultivation. Current science 2006;90(8):1113-1118.

13. Sreenivasulu Y, Chanda SK, Ahuja PS. Endosperm delays seed germination in Podophyllum hexandrum Royle - an important medicinal herb. International Seed Testing Association 2009;37:10-16. 